IZA DP No. 7107

Don't Worry, Be Happy? Happiness and Reemployment

Annabelle Krause

December 2012

Forschungsinstitut zur Zukunft der Arbeit Institute for the Study of Labor 


\title{
Don't Worry, Be Happy? Happiness and Reemployment
}

\author{
Annabelle Krause
}

IZA

\section{Discussion Paper No. 7107 \\ December 2012}

\author{
IZA \\ P.O. Box 7240 \\ 53072 Bonn \\ Germany \\ Phone: +49-228-3894-0 \\ Fax: +49-228-3894-180 \\ E-mail: iza@iza.org
}

Any opinions expressed here are those of the author(s) and not those of IZA. Research published in this series may include views on policy, but the institute itself takes no institutional policy positions. The IZA research network is committed to the IZA Guiding Principles of Research Integrity.

The Institute for the Study of Labor (IZA) in Bonn is a local and virtual international research center and a place of communication between science, politics and business. IZA is an independent nonprofit organization supported by Deutsche Post Foundation. The center is associated with the University of Bonn and offers a stimulating research environment through its international network, workshops and conferences, data service, project support, research visits and doctoral program. IZA engages in (i) original and internationally competitive research in all fields of labor economics, (ii) development of policy concepts, and (iii) dissemination of research results and concepts to the interested public.

IZA Discussion Papers often represent preliminary work and are circulated to encourage discussion. Citation of such a paper should account for its provisional character. A revised version may be available directly from the author. 


\section{ABSTRACT}

\section{Don't Worry, Be Happy? Happiness and Reemployment}

Subjective well-being is primarily treated as an outcome variable in the economic literature. However, is happiness also a driver of behavior and life's outcomes? Rich survey data of recent entrants into unemployment in Germany show that a significant inverted U-shaped relationship exists between residual happiness and an unemployed individual's future reemployment probability and the reentry wage. Residual life satisfaction displays higher (or lower) satisfaction levels than would be predicted by a number of socioeconomic and demographic characteristics. This paper is the first to show that happiness is mainly a predictor for self-employment and less for standard reemployment. Related findings suggest that happiness matters for male unemployed, and the concept of locus of control is able to explain part of the effect. If reemployment and higher wages are considered desirable outcomes for the unemployed individual and society, the shape of the effect suggests an optimal level of happiness, which is not necessarily the highest.

JEL Classification: J60, J64, I31

Keywords: $\quad$ unemployment, job search, happiness, reemployment, Germany

Corresponding author:

Annabelle Krause

IZA

P.O. Box 7240

53072 Bonn

Germany

E-mail: krause@iza.org

\footnotetext{
*I would like to thank Alfonso Flores-Lagunes, Anne Gielen, Carol Graham, Dan Hamermesh, Peter J. Kuhn, Simon Lüchinger, Andrew Oswald, Ulf Rinne, Michael Rosholm, Simone Schüller, Klaus F. Zimmermann and participants at the IZA Brown Bag Seminar and the 4th CIER/IZA Annual Workshop on Research in Labor Economics for helpful discussion and comments. This study uses the IZA Evaluation Dataset $S$, which was created by IZA with financial support of the Deutsche Post Foundation. The IZA Evaluation Dataset $S$ consists of survey information on individuals who entered unemployment in Germany between June 2007 and May 2008 (see Caliendo, Falk et al., 2011). All remaining errors are my own.
} 


\section{Introduction}

Analyzing individual happiness has become increasingly important in economic research, starting with the pioneering work of Easterlin (1974) on income, GDP per capita and happiness. ${ }^{1}$ A person's subjective well-being displays a wider (empirical) concept of their utility by incorporating both income and non-income determinants. In the same spirit, the Stiglitz report on the measurement of economic performance and social progress highlights that "emphasising well-being is important because there appears to be an increasing gap between the information contained in aggregate GDP data and what counts for common people's well-being" (Stiglitz et al., 2009, p.12). Subjective well-being and detecting its determinants can be considered the main goal in most people's lives (see, e.g., Frey and Stutzer, 2002, for a detailed overview). However, this paper adopts a different direction - namely what stands behind considering happiness as a goal. Is happiness also a driver of behavior and life's outcomes? Do societies benefit from happier citizens? There is no doubt that people do certain things to become happier or remain as happy, but do happier people also behave differently because they have different well-being levels?

This paper concentrates on unemployment dynamics - and particularly, how an unemployed individual's happiness is related with their future labor market outcomes. To date, the unemployment-happiness literature has been rather concerned with the effect of general and individual unemployment on happiness (e.g., Clark and Oswald, 1994; Winkelmann and Winkelmann, 1995, 1998; Clark et al., 2001; Di Tella et al., 2001; Kassenboehmer and Haisken-DeNew, 2009) with a broad consensus that unemployment leads to a reduction in life satisfaction. Given that there appears to be high psychological distress related to the state of unemployment and general output reduces, this constantly represents an important topic in terms of public welfare and policies. On that note, it is naturally important to understand what brings unemployed people back into employment: is the unemployment-happiness relationship exclusively a one-way street, and can this contribute to the underlying discussion about voluntary and involuntary unemployment? Therefore, the main questions of this paper are whether individual happiness influences an unemployed individual's future reemployment probability, and if reemployed, reentry wages. Since there seems to be

\footnotetext{
${ }^{1}$ The terms happiness, subjective well-being and life satisfaction are used interchangeably in this paper, as with most economists, see, e.g., Graham et al. (2004).
} 
no adaptation in life satisfaction with respect to unemployment compared to other life events (Clark et al., 2008), the relationship with reemployment appears to be of particular importance. Moreover, reemployment is measured in the data one year after the respective unemployment entry. This is a crucial point with respect to unemployment duration, as it marks the border to long-term unemployment. It is important that individuals avoid passing into long-term unemployment for several reasons. First, evidence suggests that individuals suffer from long-term unemployment with respect to their labor market opportunities and physical and mental well-being (Machin and Manning, 1999), and individuals who have been longer unemployed are less likely to find a job (Shimer, 2008). Second, 12 months are the maximum period in Germany during which prime-aged unemployed individuals are entitled to unemployment benefits receipt. ${ }^{2}$

The general contributions of this paper are first, a deeper understanding about what the unemployed's life satisfaction might influence and possible mechanisms, and second, new insights about determinants of reemployment and reentry wages. In particular, this paper aims to minimize the possible worries arising from the endogeneity of happiness. For an actual causal effect of happiness, one would need something like a random assignment or experimental data, which I do not have in the case of the observational survey data being used. A problem of endogeneity arises if an unobserved variable influences life satisfaction and future employment probability, since one would falsely interpret an effect from life satisfaction as causal in this case, despite the other factor actually determining the pattern in the relationship. Several factors related to the type of data, sample selection and empirical strategy contribute to a reduction of the endogeneity issue. Rich survey data of recent entrants into unemployment in Germany are used for the empirical analysis, with much known about their search behavior and other variables compared to other datasets. Moreover, the respondents all have been unemployed for the same amount of time, around two months on average, and thus their happiness levels are not influenced by different unemployment durations and moreover a discouraged worker effect should be small or non-existent. I am able to exclude those individuals who have not been looking for a job, and importantly those who have been looking and report to have found a job already, so the sample will only comprise actual job seekers. In addition, individual happiness and the outcome vari-

\footnotetext{
${ }^{2}$ These rules vary by age in connection with former employment duration. After these 12 months, unemployed individuals are entitled to a form of social insurance.
} 
ables are observed one year apart, since disentangling the direction of any effects would be almost impossible only using one cross-section. Finally, the empirical strategy is based on using "residual happiness" rather than absolute happiness as an explanatory variable, much in the spirit of Graham et al. (2004). The idea is to investigate whether people who had higher (or lower) happiness levels than their socioeconomic and demographic characteristics would predict having different labor market outcomes one year later. This residual element of happiness is interpreted as some sort of underlying inner disposition or cognitive bias (e.g., Cummins and Nistico, 2002), and therefore captures psychological differences between the respondents (and some random noise). Moreover, this is the first study to consider an exclusion restriction when calculating residual happiness and correcting the standard errors in the main regression due to the generated regressor.

The main results are that residual happiness has a positive and statistically significant effect on the individual's reemployment probability, however, this has a nonlinear, concave shape with the reemployment probability decreasing at the highest values of residual happiness. The relationship between residual happiness and reentry hourly wages is similar, and even more statistically robust. Further investigation shows that the reemployment result is mainly driven by self-employment. To the best of my knowledge, it has never been shown that happiness matters mainly for future self-employment and less for standard employment. The optimal level of residual happiness to maximize the self-employment probability lies at 1.9 points over what would be predicted by several covariates, given a happiness scale from 0-10. Moreover, there are rather strong gender differences with respect to the reemployment relationship, where men are driving the result and the concept of locus of control (the subjective belief about future outcomes being determined by the own actions or external factors) is able to explain part of the effect. These mechanisms also appear to be interrelated.

The remainder of this paper is organized as follows. Section 2 introduces some theoretical considerations. Section 3 describes the data and sample. Section 4 provides the results of the empirical analysis, and Section 5 concludes. 


\section{Happiness as a Driver of Job Search Behavior}

There are still only a few papers to use happiness as a determinant rather than an outcome (see, e.g., Kenny, 1999; Guven, 2012; Goudie et al., 2012; De Neve and Oswald, 2012). Using residual happiness, Guven (2011) finds an inverted U-shaped effect of residual happiness on social capital, and Graham et al. (2004) find that individuals with higher residual happiness make more money and are in better health 5 years later. Psychologists and economists have considered positive affect as an explanatory variable (for a detailed overview, see, e.g., Lyubomirsky et al., 2005).

Studies connecting happiness, job search and labor outcomes include Clark et al. (2008), finding that future unemployment reduces current wellbeing, which can be interpreted as a lead or anticipation effect. Clark (2003) finds those with a higher drop in mental well-being when becoming unemployed less likely to remain unemployed one year later and to have a shorter unemployment duration, whereas Gielen and van Ours (2011) find this drop in life satisfaction not to stimulate job finding. Psychologists find that high trait positive affect leads to greater success at obtaining follow-up job interviews (Burger and Caldwell, 2000), and that higher well-being at the age of 18 predicts higher levels of occupational attainment (Roberts et al., 2003). Overall, the findings in the related literature suggest that higher happiness leads to "better" outcomes.

In theory, the standard model of job search (McCall, 1970; Mortensen, 1970) suggests that an individual's reemployment probability depends on both the probability of receiving a job offer and accepting it, usually displayed by the individual's reservation wage. Determinants of the reservation wage are the expected wage distribution, possible search costs, the job offer arrival rate and unemployment benefits (or more generally, gains during jobless periods). Factors determining the job offer arrival rate include the general state of the labor market, the individual's job search effort (if effort is endogenized), education and experience. How would an individual's well-being enter this model?

Hermalin and Isen (2008) incorporate current emotional state into an economic modelling and decision-making framework, with the idea being a dynamic recurring relationship between affect at the beginning of a period, which influences preferences, that determine decisions or behavior, which in turn determine affect at the end of a period. With respect to reemployment, their theoretical framework suggests that employers prefer workers with 
initial happiness levels greater than some cutoff value as their work effort would be higher. ${ }^{3}$ If the happiness level is not high enough, the employers try to induce it, e.g., by offering the employee a signing bonus and thereby boosting the state of affect. In terms of the search model, the job offer arrival rate would therefore increase with happiness, since a happier worker is assumed to be more valuable for the employer through assumed higher productivity and possibly better teamwork abilities. This would be a direct channel from happiness to employment, displaying a sort of unobserved characteristic for the hiring probability besides qualification, experience and possibly other factors.

Besides this direct impact, several indirect channels exist through which happiness can affect reemployment, with the most obvious probably being job search effort. However, the direction of this effect is theoretically ambiguous: on the one hand, a very unhappy individual may suffer intensely from unemployment and tries hard to get out of it. This increases the job search intensity and/or decreases the reservation wage, both of which would lead to a higher reemployment probability. On the other hand, higher subjective well-being may display more resilience and higher motivation to search. ${ }^{4}$ In this case, higher happiness would increase the prospective employment probability through higher job search effort. Other channels include health and social contacts, which are both positively relate happiness and reemployment (see, e.g., Verkley and Stolk, 1989).

A second outcome in the empirical analysis is the reemployed individual's wage. What would the association be between happiness and future wages? It appears similar to the one discussed for the reemployment probability, namely that employers may see higher potential or prospective productivity in happier job candidates, which would result in higher wage offers. From the workers' perspective, happier candidates may exert greater bargaining power or abilities through higher self-esteem, and likewise reentry wages would increase with happiness. Therefore, theory predicts that the happier the unemployed individual, the higher is their wage when reentering the labor market.

\footnotetext{
${ }^{3}$ There is experimental evidence showing that positive affect can increase intrinsic motivation (e.g., Isen and Reeve, 2005). See also Oswald et al. (2009) for an experiment with respect to happiness and productivity.

${ }^{4}$ As Lynch (1989) points out for the empirical analysis of reemployment probabilities of young unemployed, motivation is an unobserved and omitted factor which might bias the estimates.
} 


\section{Data and Sample}

I use data from the IZA Evaluation Dataset $S$ (Caliendo, Falk et al., 2011), which is a survey of almost 18,000 individuals who entered unemployment between June 2007 and May 2008. ${ }^{5}$ One cohort of respondents was interviewed each month, therefore one wave consist of 12 cohorts. The analysis is based on the first wave of the survey, which took place on average about two months after unemployment entry, and the second wave, which took place one year after this respective unemployment entry. ${ }^{6}$ One advantage of the data lies in its specific focus on entrants into unemployment. The IZA Evaluation Dataset $S$ is thus highly appropriate for studying the processes of job search and labor market reintegration. Similar household surveys are generally designed to be representative of the whole population (e.g., the German Socio-Economic Panel Study, SOEP), which has an important drawback when studying unemployed individuals because sample sizes decrease substantially.

The data address a large variety of topics such as the individual's detailed search behavior (number of applications, search channels, reservation wages etc.), ethnic and social networks, psychological factors and life satisfaction. The exact wording of the life satisfaction question is "How satisfied are you with your life as a whole these days?" and is measured on a scale of $0-10$, where 10 represents maximum satisfaction. Self-reported life satisfaction has shown to be a valid and consistent measure of subjective wellbeing within the existing literature. Self-reports and other measures such as interview ratings, peer reports and the average daily ratio of pleasant to unpleasant moods show a strong convergence (e.g., Diener and Lucas, 2000). Other objective validity has been shown through, e.g., brain-science data (Urry et al., 2004) and compensating-differentials quality of life measures (Oswald and Wu, 2010). Moreover, Lepper (1998) shows that subjective well-being measures are fairly stable over time, and are not substantially influenced by mood states or interview circumstances.

The sample is selected with respect to the following characteristics. All individuals in the first wave must still be unemployed, thus I exclude those who are already reemployed at the time of the first interview. Given that the

\footnotetext{
${ }^{5}$ There is also an administrative part (IZA Evaluation Dataset $A$ ) of the complete dataset, which is not used in this paper.

${ }^{6}$ The survey consists of three rounds of interviews in total. Respondents are interviewed again three years after unemployment entry.
} 
interview takes place on average around two months after unemployment entry, around 25 percent of the individuals in the first wave have already exited unemployment. Respondents who claim not to have searched for a job since unemployment entry are also excluded. Most of them had already found a job. Moreover, I exclude those individuals who searched for a job but claimed at the time of the interview to certainly have a prospective job. I thereby minimize the potential bias arising from already having a job or knowledge about a future job, which causes individual happiness and future reemployment probability to increase simultaneously. The selected sample is a balanced panel of the first and second wave, and after excluding observations with missing information, I am left with a sample of 2,534 individuals per wave.

Table 1 displays summary statistics of the main variables. The information stems from the first interview, except for the employment status, hourly wage and information about life satisfaction by employment status, which are from the second wave. The mean of the newly unemployed's life satisfaction is 6.1 in the first wave, which is slightly higher than results from other studies using SOEP data, where the unemployed's life satisfaction lies rather below 6 (e.g., Winkelmann and Winkelmann, 1998; Gielen and van Ours, 2011). Considering the evolution of life satisfaction after one year, it confirms findings in the literature that individuals' life satisfaction increases when they are reemployed, in this case on average by one point to around 7. Individuals who are unemployed in the second wave suffer more than in the first wave, with their life satisfaction decreasing to around 5.5 confirming the assumption that there is no adaptation to unemployment. Almost 60 percent of the sample are employed one year after unemployment entry, reporting an hourly wage of 8.30 Euros. The average age is 38 years, and slightly less than half the sample are men. Around 17 percent of the sample are either first or second generation migrants, and around 30 percent live in East Germany. 51 percent are married, most respondents have an intermediate school and vocational degree and every fifth respondent has a degree from a technical college or university. The average last hourly wage is 7.50 Euros, and the average duration of the last job prior to unemployment entry was 52.5 months. On average, the individuals have written 15 applications since unemployment entry and use about five search channels (out of 10 possibilities, including other search channels). 64 percent of the sample look for a full-time position as opposed to a part-time position or either of the two. The most common reason for terminating the last job is layoff, 
accounting for around 44 percent of the sample, with two other prevalent reasons being the end of a temporary contract and quitting the job.

\section{Empirical Analysis}

\subsection{Residual Happiness}

To calculate residual or unexplained happiness, I first estimate an OLS life satisfaction regression with several independent variables from the first wave. ${ }^{7}$ Economists are more likely than psychologists to be worried about satisfaction scores only being ordinally meaningful. However, ordinal and cardinal estimations of life satisfaction usually generate very similar results (Ferrer-iCarbonell and Frijters, 2004; Frey and Stutzer, 2000a). ${ }^{8}$ The life satisfaction equation looks as follows:

$$
W_{i}=\beta X_{i}+\epsilon_{i},
$$

where $W_{i}$ is individual life satisfaction, $X_{i}$ are individual, household and regional characteristics, and $\epsilon_{i}$ are the residuals. Demographic and socioeconomic control variables are included, as well as wage and duration information about the last job, the amount of unemployment benefits received by the individual, and the employment status of the spouse or partner. Moreover, the federal state's unemployment rate, the reason for last job's termination and the living area's social class are controlled for. Geographical dummies for German federal states, interview cohorts and the amount of time between unemployment entry and interview are added as additional control variables.

In a second step, the residual $\epsilon_{i}$ for each individual $i$ is predicted. By

\footnotetext{
${ }^{7}$ Results from an ordered probit estimation are similar.

${ }^{8}$ If panel data are available, it is nowadays standard in the literature to use fixed effects models for happiness estimations in order to avoid biases arising from unobserved timeinvariant factors that determine both, the independent variables and happiness. One could then estimate a standard fixed effects model and include the fixed component and overall error component in the measure of residual happiness. However, since I am using only two waves in my analysis and am interested in how residual happiness is related with future outcomes, I am estimating a cross-sectional model for the first wave (see also Guven, 2011; Graham et al., 2004). Moreover, there could be a problem due to possible serial correlation of residuals in panel models as shown by Guven (2011), which cannot be used to solve reverse causation. Nevertheless, it would be important for future research to investigate whether results largely differ between the cross-sectional and fixed effects residual happiness approach.
} 
definition, the residuals are uncorrelated with the individual characteristics in the first wave, and as such present a measure for unexplained happiness laying above or below what would be expected by these observable individual characteristics. This variable may be interpreted as a proxy for inner individual disposition or cognitive bias, but also contains some noise. The living area's social class (number of households in a living area belonging to upper, upper-middle, middle, lower-middle or lower social class) serves as exclusion restriction, which is included in the first regression but not in the main regression of interest for identification reasons. The variable is comprised of information gathered by the survey institute by actual site inspections. To the best of my knowledge, this is the first study taking an exclusion restriction into account when using residual happiness. The variable is assumed to determine life satisfaction, but not directly the reemployment probability. Given that most of the variables in this dataset are somehow related to reemployment, it appears to be a reasonable fit. The variable displays the number of households in the living area - defined as a neighborhood of around 500 households. Regarding the relationship with happiness, this may also tackle a relative aspect (Luttmer, 2005), however, which should not harm the analysis. It is constructed out of factors such as household income, purchasing power parity and quality of the residential area, defined by, e.g., distance to parks and the development structure of buildings. ${ }^{9}$ The choice of the exclusion restriction is supported by evidence showing that neighborhood quality does not determine eventual earnings, unemployment likelihood and welfare participation (Oreopoulos, 2003). Moreover, residential mobility in Germany is rather low, with moving for employmentrelated reasons only accounting for a small share of around 10 percent, where commuting may be the preferred option (Caldera Sánchez and Andrews, 2011). Therefore, sorting due to employment prospects should pose no serious problem. There could be some correlation between the neighborhood's social class and the individual's own vocational degree, and in turn with the reemployment probability. However, individual educational and vocational degrees are added as control variables, thus any correlation of that kind should be taken into account in any case.

Table 2 shows the results of the life satisfaction regression, which are generally similar to standard happiness equations with a representative sample of the society or working population. In this case, the sample consists

\footnotetext{
${ }^{9}$ The results are very robust when using a variable that determines only the quality of the residential area.
} 
only of unemployed individuals, with one advantage that they have all been unemployed for a similar amount of time, which is usually not the case in other datasets. Men are significantly less happy, and happiness is U-shaped with age. Having a disability, being married to a spouse without a full or part-time job, or being single all have a statistically significant negative effect on life satisfaction. Having a higher schooling degree is mostly associated with higher happiness, likewise having a spouse with a full-time position. Second generation migrants are significantly less happy than natives, and the past hourly wage positively affects happiness. Compared to having had a job for under a year, having had a job for up to 10 years or longer has a significant positive effect on the happiness of newly-unemployed individuals. The reason for the end of the last job does not play an important role in this estimation. ${ }^{10}$ Finally, living in an area with a higher number of households belonging to the upper social class significantly raises life satisfaction, whereas a higher number of upper-middle households significantly decreases it, and a larger number of middle, lower-middle and lower class households does not influence life satisfaction.

Figure 1 shows a graph plotting the relationship between the residuals of the aforementioned regression and the employment probability in the second wave, suggesting a non-linear connection. For the most part, it is increasing until a certain point, when it experiences a sharp decrease at very positive residuals. The lowest reemployment probability is found for individuals with the highest unexplained happiness. Essentially, the graph suggests that individuals who are very unhappy or very happy both have a lower reemployment probability than individuals in between, pointing to an inversely U-shaped relationship. One possible explanation is lack of motivation, either because the person is depressed with the situation and the driving force is missing or the person is so happy that there is no motivation to change their situation.

A very important channel in this regard could be the job search effort. Table 3 shows the distribution of the means of various job search variables, comparing individuals with positive and negative residuals. Moreover, a ttest between the two subsamples is conducted. It becomes apparent that individuals with higher residual happiness are significantly more likely on average to be employed one year later, reflecting the largely increasing rela-

\footnotetext{
${ }^{10}$ The negative significant effect of taking care for relatives or others is driven only by two observations.
} 
tionship between the residuals and reemployment, yet neglecting the sharp decrease at the highest values. The other numbers in the table suggest that happier individuals exert less job search effort, for instance, writing significantly fewer applications and using significantly fewer search channels. When it comes to the use of single search channels, there is no significant difference for most of them, except searching via the job information system of the employment agency and sending out speculative applications, with happier individuals less likely to use both of these channels. With respect to the number of formal, formal active and formal passive search channels, the picture remains the same. ${ }^{11}$ However, happier individuals appear to be less likely to search for a full-time position, which could be one reason why they are searching less, as the pressure may be lower.

\subsection{Main Results}

\section{Reemployment}

The second step in the empirical analysis is to investigate whether residual happiness has any additional effects on the reemployment probability, after controlling for usual determinants of reemployment. Table 4 shows the main results when adding residual happiness as a regressor along with several other control variables. To detect any non-linearities, squared terms and quintile dummies are used besides the full values of the residual variable. Column (1) presents linear effects, indicating a positive and significant effect of increasing residual happiness on the future reemployment probability. The residual is then divided into negative (and positive) residuals by setting the positive (or negative) residuals to zero. The negative residual variable displays the absolute values rather than the negative numbers, which means that a negative sign denotes a positive effect of an increasing residual on the reemployment probability. The positive linear effect of residual happiness is driven by individuals who are less happy than would have been predicted. No significant positive effect of positive residual happiness alone can be detected. Interestingly, when adding a squared term of the positive and negative residual, the inversely U-shaped effect becomes apparent for the positive residual fraction, with a residual of 1.633 representing the turning point. This quadratic effect is not driven by outliers, since there

\footnotetext{
${ }^{11}$ See Caliendo, Schmidl et al. (2011) for a definition of formal active and formal passive search channels.
} 
are more than 500 observations involving a residual of 1.633 and above. This means that being 1.633 points happier than predicted by a number of variables maximizes an individual's reemployment probability. There is no non-linear effect for individuals with negative residuals. Finally, four dummies are added in separate regressions that indicate having a residual value higher than the first, second, third and fourth quintile of residual happiness. Again, this demonstrates the positive effect at the lower part of the residual distribution and the diminishing trend the higher the residuals. Statistical significance is also only given at the two dummies at the lower spectrum. In summary, these results suggest a positive significant effect of residual life satisfaction, particularly at the lower part of the distribution, whereas the linear effect turns non-linear inversely U-shaped in the upper part of the distribution. The effect at the top of the residual distribution may typify individuals who are voluntarily unemployed or did not try to change their life situation, since they were already very satisfied with it.

\section{Hourly Wage}

Table 5 displays regression results for the smaller sample of individuals who found a job in the second wave, with the dependent variable being their logarithmic hourly wage at the new job. Columns (1), (2) and (3) highlight a statistically significant positive effect of residual happiness on future hourly wages. However, as can be seen in column (4), the effect is not linear, as the squared term of positive residual happiness is negative. Therefore, similar to the probability of reemployment, the highest values of positive residual happiness lead to lower hourly wages. The turning point is similar to before, at a residual value of 1.36. With respect to negative residual happiness and its squared term, both coefficients show a positive statistically significant effect, bearing in mind the "reversed" sign for the non-quadratic negative residual coefficient. The quintile dummies confirm the former results with positive significant effects up to and including the third quintile. Besides having a mostly positive effect on the reemployment probability, happier individuals also earn more in their new job. Given that past hourly wage and education is controlled for in the regression, there must be something additional that the employers appreciate or expect from the happier individuals for them to be paid higher wages accordingly. Moreover, happier individuals might also be better bargainers. The negative effect at the top could be explained by individuals with the highest residual happiness not caring much about 
wages, such that they do not bargain as intensely. Oishi et al. (2007) also find that the highest levels of income are not reported by the most satisfied individuals, but rather by moderately satisfied individuals.

The first question arising at this point is why such effects occur, with the forthcoming section attempting to explain where the effect comes from. However, the mechanisms shown in the following focus on reemployment and not wages. The channels for these two outcome variables appear not to be similar, and only hold with respect to the reemployment relationship.

\subsection{Potential Mechanisms}

\section{Male vs. Female}

Table 6 show the results for reemployment separately by gender, and to the best of my knowledge, such differential effects for men and women have never been shown. Interestingly, the results suggest that the male unemployed are driving the main results, as the effects for women are not statistically significant and substantially smaller than for men. The linear residual happiness coefficients are significantly different from each other, in an interesting and perhaps unexpected pattern. Why should happiness only be a driver for unemployed males with respect to their reemployment probability? It could be that this selected sample displays a non-representative selection for males and females, in the sense that men may still feel more attached to the labor market than women, and thus not being very unhappy is more important for men. Additionally, the male residual happiness distribution has longer tails (women may reply more carefully or avoid outliers), therefore effects at the bottom and top can be driven by the male responses. The male and female reemployment rate is virtually the same. Further research would be interesting in considering whether this differential pattern also exists in other settings, not only connected to unemployed individuals. ${ }^{12}$ Dividing the sample by education does not lead to differential results.

\section{Self-Employment}

Table 7 shows the results when differentiating standard employment and self-employment in the second wave, with both possibilities being jointly

\footnotetext{
${ }^{12}$ Graham and Chattopadhyay (2012) consider gender differences with respect to wellbeing around the world. However, well-being serves as an outcome variable rather than a driver of behavior in their study.
} 
analyzed thus far. The results appear quite intriguing, with columns (1) to (5) showing the estimations where the dependent variable is equal to 1 if an individual became reemployed, excluding the self-employed. Compared to the main results, all coefficients decrease, and moreover, most statistical significance disappears. The nonlinear shape at the top is still apparent, but only significant at the 10 percent level. Columns (6) to (10) show the results when only considering self-employment, with all coefficients increasing compared to the main results, being up to four times larger than the coefficients for standard employment. Moreover, they are all statistically significant, except the squared negative happiness residual term, which suggests a clear and robust inversely U-shaped relationship between residual happiness and self-employment. The turning point for the self-employed is at a residual happiness value of 1.9 , which is slightly higher than for the whole sample. This result can be a valuable contribution given the increasing interest and literature regarding personality and entrepreneurship (see, e.g., Caliendo, Fossen et al., 2011; Caliendo and Kritikos, 2012).

\section{Locus of Control}

One advantage of the data set used for this analysis is the variety of topics covered, therefore the main results can be connected to variables that are rarely available, which to my knowledge has not been achieved in such a way. There are a number of personality questions in the questionnaire, with some of them referring to the locus of control. This is a concept involving the subjective belief of whether life's outcomes are outside one's control and can rather be attributed to fate or luck (external), or alternatively whether life's outcomes depend on one's own decisions and behavior (internal). Individuals with an internal locus of control have been found to be associated with higher happiness (Verme, 2009; Becker et al., 2012), and external individuals have been associated with a lower probability of full-time employment (Braakmann, 2009) and lower reservation wages (Caliendo et al., 2010), whereas internal individuals exert higher job search effort (Caliendo et al., 2010).

By adding this personality dimension to the relationship, can the locus of control concept explain the residual life satisfaction effect? Table 8 dis- 
plays the results when including the standardized locus of control index, ${ }^{13}$ showing that the residual happiness effect can be partly explained by this factor, as all coefficients decrease at least slightly when including the standardized index of locus of control as a control variable. However, the effects of only negative residual happiness and the inversely U-shaped effect at the high positive residual values are still significantly different from zero.

All three potential channels appear to be interrelated, as men are more likely to be self-employed, and those self-employed also had higher internal locus of control levels in the first wave. However, further differentiating the male sample by self-employment and employment shows that there is still a happiness effect for men with respect to standard employment (that is not apparent for women). ${ }^{14}$ Generally showing that happiness is a predictor of self-employment has not previously been achieved to my knowledge, and can represent important information for academic research and policymakers.

\subsection{Attrition}

Panel mortality is a common problem related to longitudinal datasets. Attrition may lead to selection bias, which is why the main results are checked for robustness as follows. With respect to the dataset used for this analysis, around 50 percent of the original sample can be reached for a second interview. In order to control for possible attrition bias, inverse probability weighting is applied. Assuming the selection process is based on observables this procedure is $\sqrt{N}$-consistent (Wooldridge, 2002).

This method involves two steps, the first step of which is to estimate a probit or logit model of the probability to reply in the second wave on several independent characteristics of the first wave. In the second step, inverse probabilities are calculated for each individual with the fitted probabilities to reply in the second wave. The main estimation results are weighted us-

\footnotetext{
${ }^{13}$ Constructing the locus of control index relies heavily on Caliendo et al. (2010). Respondents are asked ten statements related to attitudes towards life and the future and are supposed to agree on a scale from 1 to 7. Caliendo et al. (2010) performed a factor analysis that attributed certain items to the internal locus of control concept and certain others to the external one. For the full index, all items are standardized and the aggregated external ones are subtracted from the aggregated internal items. The full index is then standardized once more and enters the regression as such. A higher value refers to a more internal locus of control.

${ }^{14}$ Results are not shown.
} 
ing these inverse probability weights, which take higher dropout rates with respect to certain individual characteristics into account.

The results of a logit estimation are shown in Table 9, with the probability to reply in the second wave being the dependent variable. ${ }^{15}$ Compared to the first cohort, most cohorts are significantly more likely to reply in the second wave. The same is true for higher vocational degrees and whether children are present in the household. The larger the timelag between the actual unemployment entry and the first interview, - there is an average time gap of two months - the lower the probability to give a second interview. Furthermore, first generation migrants are also more likely to drop out. Other characteristics such as information about the last job, gender, geographical distribution, age, marital status, life satisfaction, residual happiness and locus of control are not relevant for the selection process. ${ }^{16}$

Table 10 shows the main results correcting for panel mortality, with the first five columns displaying the results for future reemployment and the last five columns the results for future wages. The effects with respect to reemployment slightly decrease, and the main effect of residual happiness loses its statistically significance, whereas the nonlinear effect for positive residual happiness is particularly robust to attrition bias. Further analysis shows that dropping around 100 observations with weights above 4.5 (the overall mean is 2.07 with a standard deviation of 0.84 , and the median is 1.80 ) leads to very robust main results. In summary, there appears to be some selection bias with respect to the results of reemployment which, however, is driven by outliers with very large weights. The results of future wages are very robust with respect to attrition as shown by columns (6) - (10). Some magnitudes are slightly smaller than without correcting for panel mortality, yet this does not change the former conclusions. The results are also robust to dropping individuals with weights larger than 4.5. Therefore, correcting for attrition bias does not seem to alter the key findings of the main analysis.

\footnotetext{
${ }^{15}$ Results are not altered using a probit estimation.

${ }^{16}$ Life satisfaction, residual happiness and locus of control are left out of the estimation shown here, given that they do not contribute to the selection process.
} 


\section{Conclusions}

This study investigates the effect of an individual's happiness level on future labor market outcomes. In particular, an inflow sample into unemployment in Germany is used to calculate residual happiness, which displays higher (or lower) satisfaction levels than would be predicted by a number of demographic and socioeconomic characteristics. In a second step, the effect of this residual on future labor market outcomes is subsequently analyzed. There is a statistically significant inverted U-shaped effect of residual happiness on an unemployed individual's future reemployment and reentry wages, even after controlling for demographic and socioeconomic characteristics. Further investigation offers three mechanisms, that appear to also be interrelated, and have not previously been shown in this context: $a$ ) happiness matters mainly for future self-employment and less for standard employment; $b$ ) happiness matters only for male unemployed and not for females; and $c$ ) and the concept of locus of control is able to explain part of the effect. The result regarding self-employment is a new and interesting finding that may have implications for the literature on entrepreneurship. However, this study is only representative of the selected unemployment population in Germany. Future research investigating gender effects could shed light upon whether significant differences between men and women also exist outside the unemployment or labor market context. Furthermore, the connection between happiness and personality traits should be investigated in greater detail whenever possible, to better understand the driving forces behind their relationship.

One motivation for this study is to understand what happiness displays for individuals. There is no doubt that it can be considered as the ultimate goal in life for most people. Individuals do certain things because they derive utility or satisfaction from them, and therefore happiness represents a goal in itself. However, there is also a second goal that goes one step further: an individual's satisfaction also makes them do things or not, which in turn leads to certain outcomes. Consequently, given a positive connection, happiness would lead people to make "better" choices for themselves and their lives, which would hopefully translate into "better" choices for society. Generally, this positive connection between happiness and future outcomes seems to exist. However, this study shows that this effect is not linear, at least in this special setting with unemployed individuals. If reemployment and higher reentry wages are considered desirable outcomes for the un- 
employed individual and society, the shape of the effect suggests that the optimal level of happiness is not necessarily the highest (Frey and Stutzer, 2000b). Being too happy may lead to the loss of motivation and resilience to pursue one's life in a conscious and healthy manner. In the same spirit, psychologists have found the optimal level of happiness in the domains of volunteer work and personal relationships to be the highest, whereas the optimal level of happiness for achievement outcomes such as income and education is a moderately high level. Oishi et al. (2007) state that a slight dissatisfaction can serve as motivation to achieve more, earn more money, and in other words, to (self-)improve, which is confirmed by the findings of this paper. Maximizing happiness should not necessarily be the goal that future policy-makers should consider. Instead, optimizing happiness appears to be the enduring and desirable long-term ambition.

\section{References}

Becker, A., T. Deckers, T. Dohmen, A. Falk, and F. Kosse (2012). The Relationship Between Economic Preferences and Psychological Personality Measures. Annual Review of Economics 4, 453-478.

Braakmann, N. (2009). The Role of Psychological Traits for the Gender Gap in Full-time Employment and Wages: Evidence from Germany. SOEPpapers on Multidisciplinary Panel Data Research 162, DIW Berlin.

Burger, J. M. and D. F. Caldwell (2000). Personality, Social Activities, Job-Search Behavior and Interview Success: Distinguishing Between PANAS Trait Positive Affect and NEO Extraversion. Motivation and Emotion 24(1), 51-62.

Caldera Sánchez, A. and D. Andrews (2011). Residential Mobility and Public Policy in OECD Countries. OECD Journal: Economic Studies 2011/1, 185-206.

Caliendo, M., D. Cobb-Clark, and A. Uhlendorff (2010). Locus of Control and Job Search Strategies. IZA Discussion Paper 4750, Institute for the Study of Labor (IZA), Bonn.

Caliendo, M., A. Falk, L. C. Kaiser, H. Schneider, A. Uhlendorff, G. J. van den Berg, and K. F. Zimmermann (2011). The IZA Evaluation Dataset: Towards Evidence-based Labour Policy-Making. International Journal of Manpower 32(7), 731-752.

Caliendo, M., F. Fossen, and A. Kritikos (2011). Personality Characteristics and the Decision to Become and Stay Self-Employed. IZA Discussion Paper 5566, Institute for the Study of Labor (IZA), Bonn.

Caliendo, M. and A. Kritikos (2012). Searching for the Entrepreneurial Personality: New Evidence and Avenues for Further Research. Journal of Economic Psychology 33(2), 319324.

Caliendo, M., R. Schmidl, and A. Uhlendorff (2011). Social Networks, Job Search Methods and Reservation Wages: Evidence for Germany. International Journal of Manpower 32(7), 796-824.

Clark, A. (2003). Unemployment as a Social Norm: Psychological Evidence from Panel Data. Journal of Labor Economics 21(2), 323-351. 
Clark, A., Y. Georgellis, and P. Sanfey (2001). Scarring: The Psychological Impact of Past Unemployment. Economica 68(270), 221-241.

Clark, A. and A. Oswald (1994). Unhappiness and Unemployment. The Economic Journal 104, 648-659.

Clark, A. E., E. Diener, Y. Georgellis, and R. E. Lucas (2008). Lags and Leads in Life Satisfaction: A Test of the Baseline Hypothesis. The Economic Journal 118, F222-F243.

Cummins, R. A. and H. Nistico (2002). Maintaining Life Satisfaction: The Role of Positive Cognitive Bias. Journal of Happiness Studies 3(1), 37-69.

De Neve, J.-E. and A. Oswald (2012). Estimating the Influence of Life Satisfaction and Positive Affect on Later Income Using Sibling Fixed Effects. Proceedings of the National Academy of Sciences 109(49), 19953-19958.

Di Tella, R., R. J. MacCulloch, and A. Oswald (2001). Preferences over Inflation and Unemployment: Evidence from Surveys of Happiness. The American Economic Review 91, 335-341.

Diener, E. and R. Lucas (2000). Subjective Emotional Well-Being. In M. Lewis and J. Haviland (Eds.), Handbook of Emotions, New York, pp. 325-337. Guilford. 2nd edition.

Easterlin, R. (1974). Does Economic Growth Improve the Human Lot? Some Empirical Evidence. In P. David and M. Reder (Eds.), Nations and Households in Economic Growth: Essays in Honor of Moses Abramovitz, New York and London, pp. 89-125. Academic Press.

Ferrer-i-Carbonell, A. and Frijters, P. (2004). How Important is Methodology for the Estimates of the Determinants of Happiness? The Economic Journal 114, 641-659.

Frey, B. S. and A. Stutzer (2000a). Happiness, Economy and Institutions. The Economic Journal 110, 918-938.

Frey, B. S. and A. Stutzer (2000b). Maximizing Happiness? German Economic Review 1(2), 145-167.

Frey, B. S. and A. Stutzer (2002). What can Economists Learn from Happiness Research? Journal of Economic Literature 40, 402-435.

Gielen, A. C. and J. C. van Ours (2011). Unhappiness and Job Finding. IZA Discussion Paper 6320, Institute for the Study of Labor (IZA), Bonn.

Goudie, R. J. B., S. Mukherjee, J.-E. D. Neve, A. J. Oswald, and S. Wu (2012). Happiness as a Driver of Risk-Avoiding Behavior. Discussion Paper 1126, Centre for Economic Performance, London.

Graham, C. and S. Chattopadhyay (2012). Gender and Well-Being around the World. The Brookings Institution.

Graham, C., A. Eggers, and S. Sukhtankar (2004). Does Happiness Pay? An Exploration Based on Panel Data from Russia. Journal of Economic Behavior and Organization 55, 319-342.

Guven, C. (2011). Are Happier People Better Citizens? Kyklos 64(2), 178-192.

Guven, C. (2012). Reversing the Question: Does Happiness Affect Consumption and Savings Behavior? Journal of Economic Psychology 33, 701-717.

Hermalin, B. E. and A. M. Isen (2008). A Model of the Effect of Affect on Economic Decision Making. Quantitative Marketing and Economics 6, 17-40.

Isen, A. M. and J. Reeve (2005). The Influence of Positive Affect on Intrinsic and Extrinsic Motivation: Facilitating Enjoyment of Play, Responsible Work Behavior, and Self-Control. Motivation and Emotion 29(4), 297-325.

Kassenboehmer, S. and J. Haisken-DeNew (2009). You're Fired! The Causal Negative Effect of Unemployment on Life Satisfaction. The Economic Journal 119, 448-462.

Kenny, C. (1999). Does Growth Cause Happiness, or Does Happiness Cause Growth? Kyklos 52(1), 3-23.

Lepper, H. S. (1998). Use of Other-Reports to Validate Subjective Well-Being Measures. Social Indicators Research 44, 367-379.

Luttmer, E. F. P. (2005). Neighbors as Negatives: Relative Earnings and Well Being. Quarterly Journal of Economics 120(3), 963-1002. 
Lynch, L. M. (1989). The Youth Labor Market in the Eighties: Determinants of Reemployment Probabilities for Young Men and Women. The Review of Economics and Statistics 71(1), 37-45.

Lyubomirsky, S., L. King, and E. Diener (2005). The Benefits of Frequent Positive Affect: Does Happiness Lead to Success? Psychological Bulletin 131, 803-855.

Machin, S. and A. Manning (1999). The Causes and Consequences of Longterm Unemployment in Europe. In O. Ashenfelter and D. Card (Eds.), Handbook of Labor Economics, Volume 3, New York, pp. 3085-3139. Elsevier.

McCall, J. (1970). Economics of Information and Job Search. Quarterly Journal of Economics 84(1), 113-126.

Mortensen, D. T. (1970). Job Search, the Duration of Unemployment, and the Philipps Curve. American Economic Review 60(5), 847-862.

Murphy, K. M. and R. H. Topel (1985). Estimation and Inference in Two-Step Econometric Models. Journal of Business and Economic Statistics 3(4), 370-379.

Oishi, S., E. Diener, and R. E. Lucas (2007). The Optimum Level of Well-Being - Can People Be Too Happy? Perspectives on Psychological Science 2(4), 346-360.

Oreopoulos, P. (2003). The Long-Run Consequences of Living in a Poor Neighborhood. Quarterly Journal of Economics 118(4), 1533-1575.

Oswald, A., E. Proto, and D. Sgroi (2009). Happiness and Productivity. IZA Discussion Paper 4645, Institute for the Study of Labor (IZA), Bonn.

Oswald, A. and S. Wu (2010). Objective Confirmation of Subjective Measures of Human Well-Being: Evidence from the U.S.A. Science 327(5965), 576-579.

Roberts, B. W., A. Caspi, and T. E. Moffitt (2003). Work Experiences and Personality Development in Young Adulthood. Journal of Personality and Social Psychology 84(3), 582-593.

Shimer, R. (2008). The Probability of Finding a Job. American Economic Review: Papers and Proceedings 98(2), 268-273.

Stiglitz, J. E., A. Sen, and J.-P. Fitoussi (2009). Report by the Commission on the Measurement of Economic Performance and Social Progress. www.stiglitz-sen-fitoussi.fr.

Urry, H. L., J. B. Nitschke, I. Dolski, D. C. Jackson, K. M. Dalton, C. J. Mueller, M. A. Rosenkranz, C. D. Ryff, B. H. Singer, and R. J. Davidson (2004). Making a Life Worth Living - Neural Correlates of Well-Being. Psychological Science 15(6), 367-372.

Verkley, H. and J. Stolk (1989). Does Happiness Lead Into Idleness? In R. Veenhoven (Ed.), How Harmfull is Happiness? Consequences of Enjoying Life or not, Rotterdam, The Netherlands. University Press.

Verme, P. (2009). Happiness, Freedom and Control. Journal of Economic Behavior and Organization 71, 146-161.

Winkelmann, L. and R. Winkelmann (1995). Unemployment: Where Does it Hurt? Discussion Paper 1093, Center for Economic Policy Research.

Winkelmann, L. and R. Winkelmann (1998). Why are the Unemployed So Unhappy? Evidence from Panel Data. Economica 65, 1-15.

Wooldridge, J. (2002). Econometric Analysis of Cross Section and Panel Data. Cambridge, MA: MIT Press. 
Table 1: Descriptive Statistics of Main Variables

\begin{tabular}{|c|c|c|}
\hline Variable & Mean & Std. Dev. \\
\hline Life Satisfaction (Wave 1) & 6.144 & $(2.128)$ \\
\hline Life Satisfaction of the Employed (Wave 2) & 7.079 & $(1.777)$ \\
\hline Life Satisfaction of the Unemployed (Wave 2) & 5.486 & $(2.380)$ \\
\hline Employed (Wave 2) & 0.588 & $(0.492)$ \\
\hline Hourly Wage (Wave 2) (Euros) - If Employed & 8.302 & $(8.298)$ \\
\hline Age & 38.243 & $(9.863)$ \\
\hline Male & 0.467 & $(0.499)$ \\
\hline Native & 0.826 & $(0.379)$ \\
\hline 1st Generation Migrant & 0.092 & $(0.289)$ \\
\hline 2nd Generation Migrant & 0.082 & $(0.274)$ \\
\hline Eastern Germany & 0.285 & $(0.452)$ \\
\hline Married & 0.507 & $(0.500)$ \\
\hline No Formal Educational Degree & 0.010 & $(0.099)$ \\
\hline Secondary School (9 Yrs.) & 0.276 & $(0.447)$ \\
\hline Secondary School (10 Yrs.) & 0.421 & $(0.494)$ \\
\hline Technical College Entrance Qualification (11-12 Yrs.) & 0.058 & $(0.233)$ \\
\hline General Qualification for University Entrance (12-13 Yrs.) & 0.235 & $(0.424)$ \\
\hline No Formal Vocational Degree & 0.085 & $(0.279)$ \\
\hline Apprenticeship (Dual System) & 0.592 & $(0.492)$ \\
\hline Specialized Vocational School & 0.140 & $(0.347)$ \\
\hline University, Technical College & 0.183 & $(0.387)$ \\
\hline Net Hourly Wage of Last Job (Euros) & 7.488 & $(3.981)$ \\
\hline Duration of Last Job (in Months) & 52.542 & $(77.663)$ \\
\hline Number of Applications Sent & 15.424 & $(19.277)$ \\
\hline Number of Search Channels Used & 5.273 & $(1.616)$ \\
\hline Search for Full-Time Job & 0.643 & $(0.479)$ \\
\hline Reason for Termination of Previous Job: & & \\
\hline Quit & 0.107 & $(0.309)$ \\
\hline Layoff & 0.440 & $(0.496)$ \\
\hline Employer and Employee Agreed on Termination of Contract & 0.082 & $(0.275)$ \\
\hline End of Temporary Contract & 0.219 & $(0.414)$ \\
\hline Firm Closure & 0.073 & $(0.260)$ \\
\hline End of Self-Employment & 0.013 & $(0.115)$ \\
\hline Parental Leave & 0.018 & $(0.132)$ \\
\hline Care for Person in Need & 0.001 & $(0.028)$ \\
\hline Other Reason & 0.047 & $(0.212)$ \\
\hline \# of Observations & \multicolumn{2}{|c|}{2,534} \\
\hline
\end{tabular}

Source: IZA Evaluation Dataset S, own calculations.

Notes: All variables display characteristics from wave 1 if not indicated otherwise. Differing number of observations: Life Satisfaction of the Employed (Wave 2): 1,489; Life Satisfaction of the Unemployed (Wave 2): 777; Hourly Wage (Wave 2) (Euros) - If Employed: 1,381. 
Table 2: OLS Life Satisfaction Estimation First Wave

\begin{tabular}{|c|c|c|}
\hline \multirow{2}{*}{ Male } & \multicolumn{2}{|c|}{ Life Satisfaction in Wave 1} \\
\hline & $-0.212^{* *}$ & $(0.091)$ \\
\hline Age & $-0.088^{* *}$ & $(0.038)$ \\
\hline Age Squared & $0.090^{*}$ & $(0.050)$ \\
\hline Disabled & $-0.305^{*}$ & $(0.170)$ \\
\hline \multicolumn{3}{|l|}{ Marital Status (Reference: Divorced/Widowed) } \\
\hline Married & $-0.542^{* * *}$ & $(0.167)$ \\
\hline Single & $-0.540 * * *$ & $(0.142)$ \\
\hline Partner (Reference: No Partner) & -0.286 & $(0.236)$ \\
\hline \multicolumn{3}{|l|}{ Employment Status Spouse (Reference: not Full-Time/Part-Time Employed) } \\
\hline Full-Time Employed & $0.888^{* * *}$ & $(0.140)$ \\
\hline Part-Time Employed & 0.328 & $(0.230)$ \\
\hline \multicolumn{3}{|l|}{ Employment Status Partner (Reference: not Full-Time/Part-Time Employed) } \\
\hline Full-Time Employed & -0.085 & $(0.258)$ \\
\hline Part-Time Employed & 0.710 & $(0.529)$ \\
\hline \multicolumn{3}{|l|}{ Educational Degree (Reference: No Degree) } \\
\hline Secondary School (9 yrs.) & 0.597 & $(0.418)$ \\
\hline Secondary School (10 yrs.) & $0.723^{*}$ & $(0.418)$ \\
\hline Technical College Entrance Qualification (11-12 yrs.) & 0.546 & $(0.447)$ \\
\hline General Qualification for University Entrance (12-13 yrs.) & $0.806^{*}$ & $(0.429)$ \\
\hline \multicolumn{3}{|l|}{ Vocational Degree (Reference: No Degree) } \\
\hline Apprenticeship (Dual System) & 0.124 & $(0.156)$ \\
\hline Specialized Vocational School & 0.050 & $(0.186)$ \\
\hline University, Technical College & -0.117 & $(0.199)$ \\
\hline Children in Household & 0.208 & $(0.175)$ \\
\hline Number of Children in Household & 0.117 & $(0.099)$ \\
\hline \multicolumn{3}{|l|}{ Migrant Status (Reference: Native) } \\
\hline 1st Generation Migrant & 0.032 & $(0.148)$ \\
\hline 2nd Generation Migrant & $-0.331^{* *}$ & $(0.151)$ \\
\hline Net Hourly Wage of Last Job (Euros) & $0.046^{* * *}$ & $(0.012)$ \\
\hline \multicolumn{3}{|l|}{ Duration of Last Job (Reference: Until 1 Year) } \\
\hline 1 to 5 Years & 0.143 & $(0.097)$ \\
\hline 5 to 10 Years & $0.367^{* * *}$ & $(0.137)$ \\
\hline More than 10 Years & $0.331^{* *}$ & $(0.146)$ \\
\hline 0 Months & $-0.692^{*}$ & $(0.411)$ \\
\hline Log of Unemployment Benefits & 0.019 & $(0.016)$ \\
\hline State Unemployment Rate & -0.078 & $(0.212)$ \\
\hline \multicolumn{3}{|l|}{ Termination of Previous Job (Reference: Temporary Contract) } \\
\hline Quit & 0.102 & $(0.159)$ \\
\hline Layoff & -0.091 & $(0.111)$ \\
\hline Employer and Employee Agreed & 0.216 & $(0.175)$ \\
\hline Firm Closure & 0.063 & $(0.181)$ \\
\hline End of Self-Employment & -0.328 & $(0.365)$ \\
\hline Parental Leave & 0.313 & $(0.332)$ \\
\hline Care for Person in Need & $-2.507^{*}$ & $(1.452)$ \\
\hline Other & -0.207 & $(0.212)$ \\
\hline Nb. of Households in Living Area Belonging to Upper Social Class & $0.001^{*}$ & $(0.001)$ \\
\hline Nb. of Households in Living Area Belonging to Upper-Middle Social Class & $-0.001^{* *}$ & $(0.0004)$ \\
\hline Nb. of Households in Living Area Belonging to Middle Social Class & 0.000 & $(0.0003)$ \\
\hline Nb. of Households in Living Area Belonging to Lower-Middle Social Class & 0.000 & $(0.0002)$ \\
\hline Nb. of Households in Living Area Belonging to Lower Social Class & -0.000 & $(0.001)$ \\
\hline Constant & $7.758^{* * *}$ & $(1.960)$ \\
\hline \# of Observations & \multicolumn{2}{|c|}{2,534} \\
\hline$R^{2}$ & \multicolumn{2}{|c|}{0.114} \\
\hline
\end{tabular}

Source: IZA Evaluation Dataset S, own calculations. State unemployment rates from the federal unemployment agency.

Notes: Standard errors in parentheses. Further control variables include dummies for German federal states, interview cohorts, time between unemployment entry and interview.

*** significant at $1 \%$; ** significant at $5 \%$; * significant at $10 \%$. 
Figure 1: Residual Happiness and Future Reemployment Probability

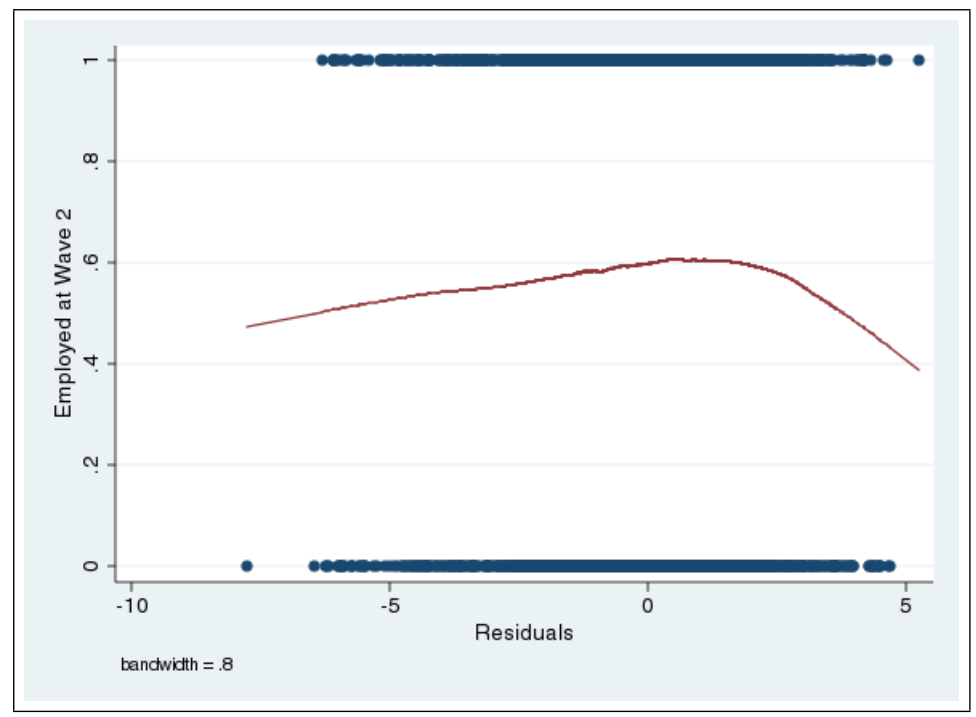

Source: IZA Evaluation Dataset S, own calculations.

Note: Based on results from a locally weighted regression. 
Table 3: Job Search Effort

\begin{tabular}{|c|c|c|c|}
\hline & Negative Residual & Positive Residual & p-value of t-test \\
\hline Employed in Second Wave & $\begin{array}{c}0.565 \\
(0.496)\end{array}$ & $\begin{array}{c}0.607 \\
(0.489)\end{array}$ & 0.034 \\
\hline Number of Applications Sent & $\begin{array}{c}17.221 \\
(22.957)\end{array}$ & $\begin{array}{c}13.921 \\
(15.393)\end{array}$ & 0.000 \\
\hline Number of Search Channels Used & $\begin{array}{c}5.377 \\
(1.608)\end{array}$ & $\begin{array}{c}5.186 \\
(1.617)\end{array}$ & 0.003 \\
\hline Number of Formal Search Channels Used & $\begin{array}{c}4.515 \\
(1.511)\end{array}$ & $\begin{array}{c}4.342 \\
(1.488)\end{array}$ & 0.004 \\
\hline Search for Full-Time Job & $\begin{array}{c}0.675 \\
(0.469)\end{array}$ & $\begin{array}{c}0.617 \\
(0.486)\end{array}$ & 0.002 \\
\hline \multicolumn{4}{|l|}{ Search Channel Used: } \\
\hline Newspaper Advertisement & $\begin{array}{c}0.881 \\
(0.324)\end{array}$ & $\begin{array}{c}0.869 \\
(0.338)\end{array}$ & 0.347 \\
\hline Advertisement Posted & $\begin{array}{c}0.150 \\
(0.357)\end{array}$ & $\begin{array}{c}0.128 \\
(0.335)\end{array}$ & 0.116 \\
\hline Job Information System & $\begin{array}{c}0.678 \\
(0.468)\end{array}$ & $\begin{array}{c}0.628 \\
(0.483)\end{array}$ & 0.009 \\
\hline Informal Search (Friends and Relatives) & $\begin{array}{c}0.862 \\
(0.345)\end{array}$ & $\begin{array}{c}0.844 \\
(0.363)\end{array}$ & 0.203 \\
\hline Agent of Employment Agency & $\begin{array}{c}0.736 \\
(0.441)\end{array}$ & $\begin{array}{c}0.717 \\
(0.450)\end{array}$ & 0.304 \\
\hline Internet & $\begin{array}{c}0.895 \\
(0.306)\end{array}$ & $\begin{array}{c}0.888 \\
(0.316)\end{array}$ & 0.548 \\
\hline Private Agent with Agency Voucher & $\begin{array}{c}0.098 \\
(0.297)\end{array}$ & $\begin{array}{c}0.091 \\
(0.288)\end{array}$ & 0.571 \\
\hline Private Agent without Agency Voucher & $\begin{array}{c}0.179 \\
(0.384)\end{array}$ & $\begin{array}{c}0.159 \\
(0.366)\end{array}$ & 0.166 \\
\hline Speculative Application & $\begin{array}{c}0.696 \\
(0.460)\end{array}$ & $\begin{array}{c}0.659 \\
(0.474)\end{array}$ & 0.051 \\
\hline Other Search Channel & $\begin{array}{c}0.205 \\
(0.404)\end{array}$ & $\begin{array}{c}0.202 \\
(0.402)\end{array}$ & 0.885 \\
\hline \# of Observations & 1,154 & 1,380 & \\
\hline
\end{tabular}

Source: IZA Evaluation Dataset S, own calculations.

Notes: All variables display characteristics from wave 1 except being employed at wave 2 . 


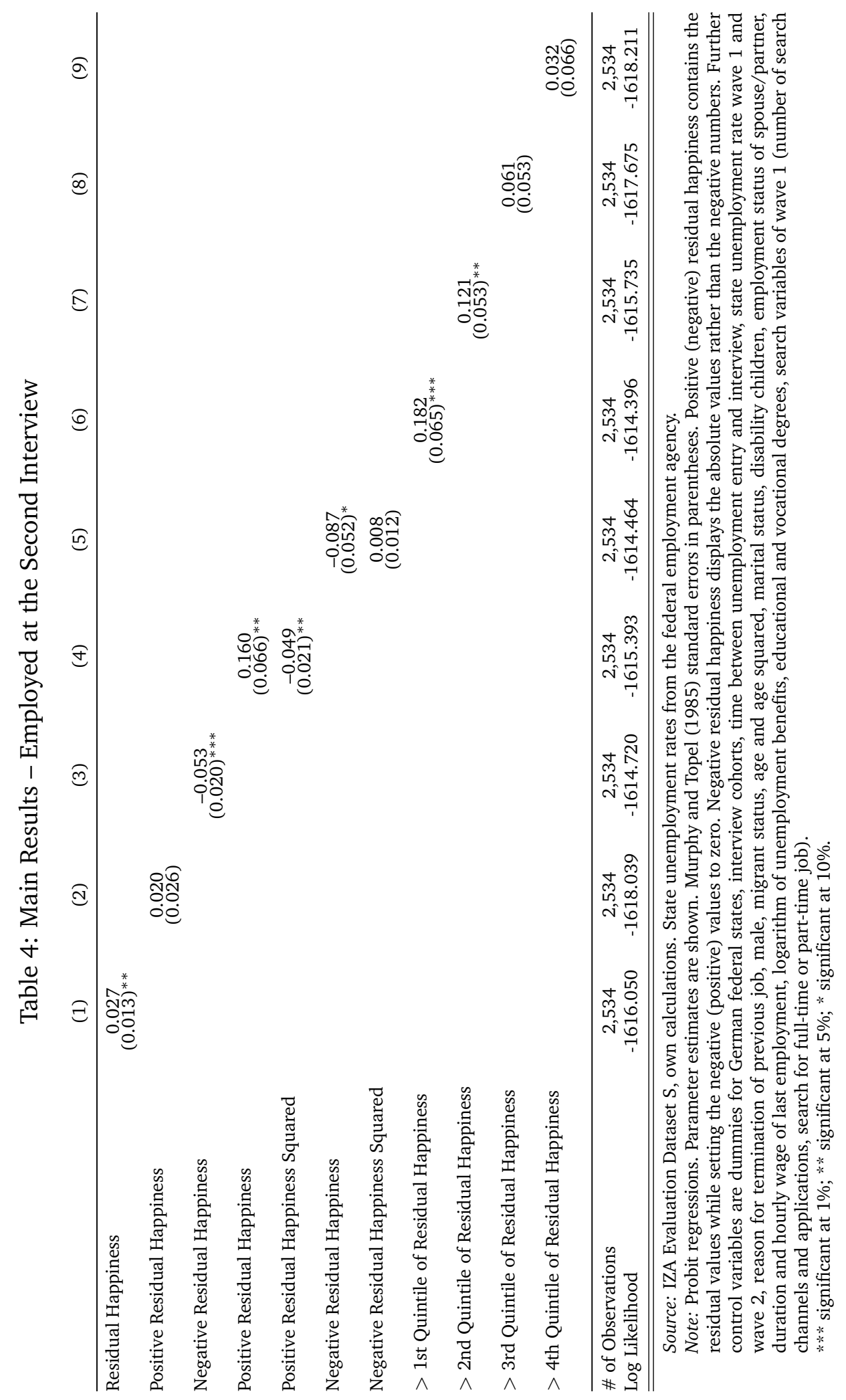




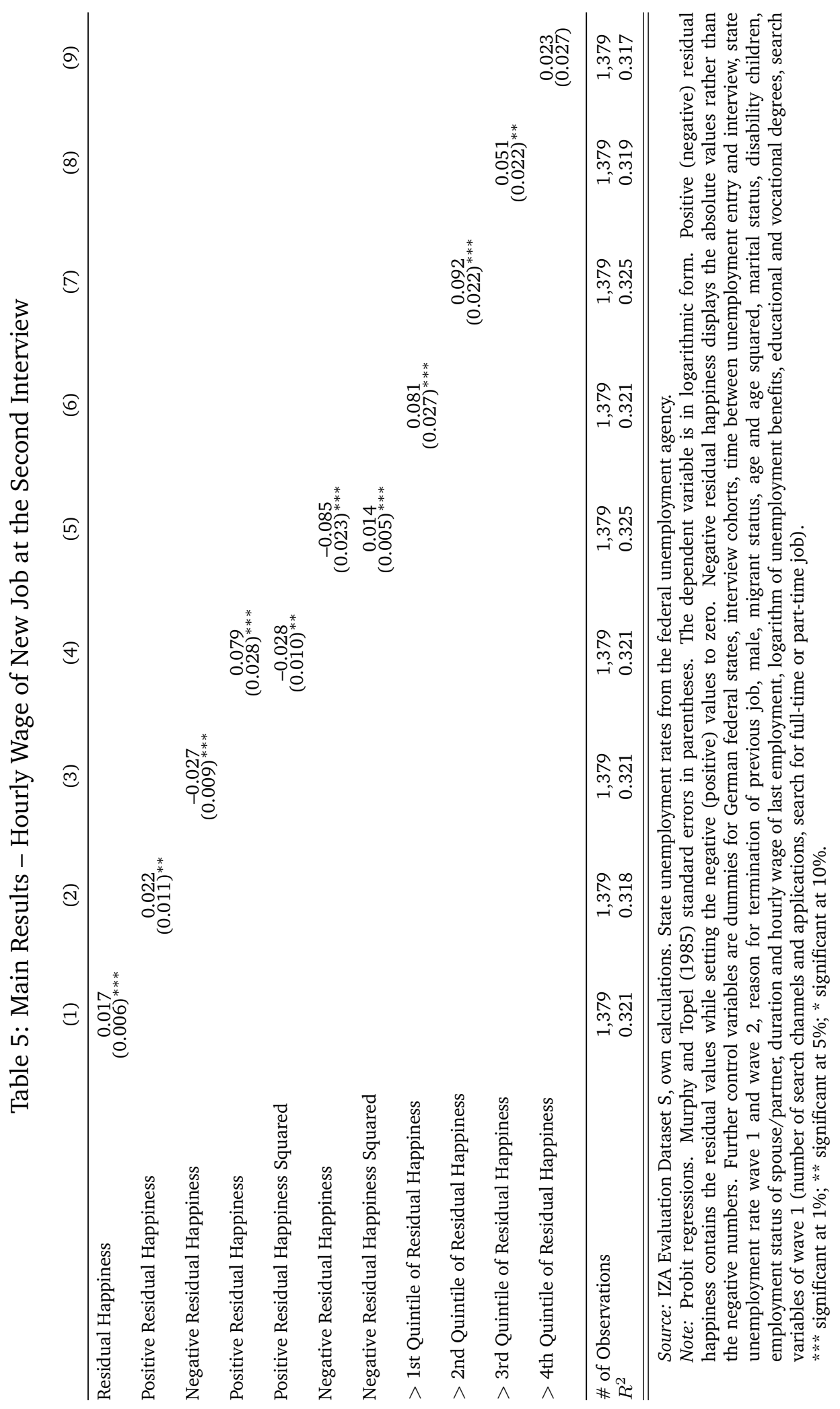




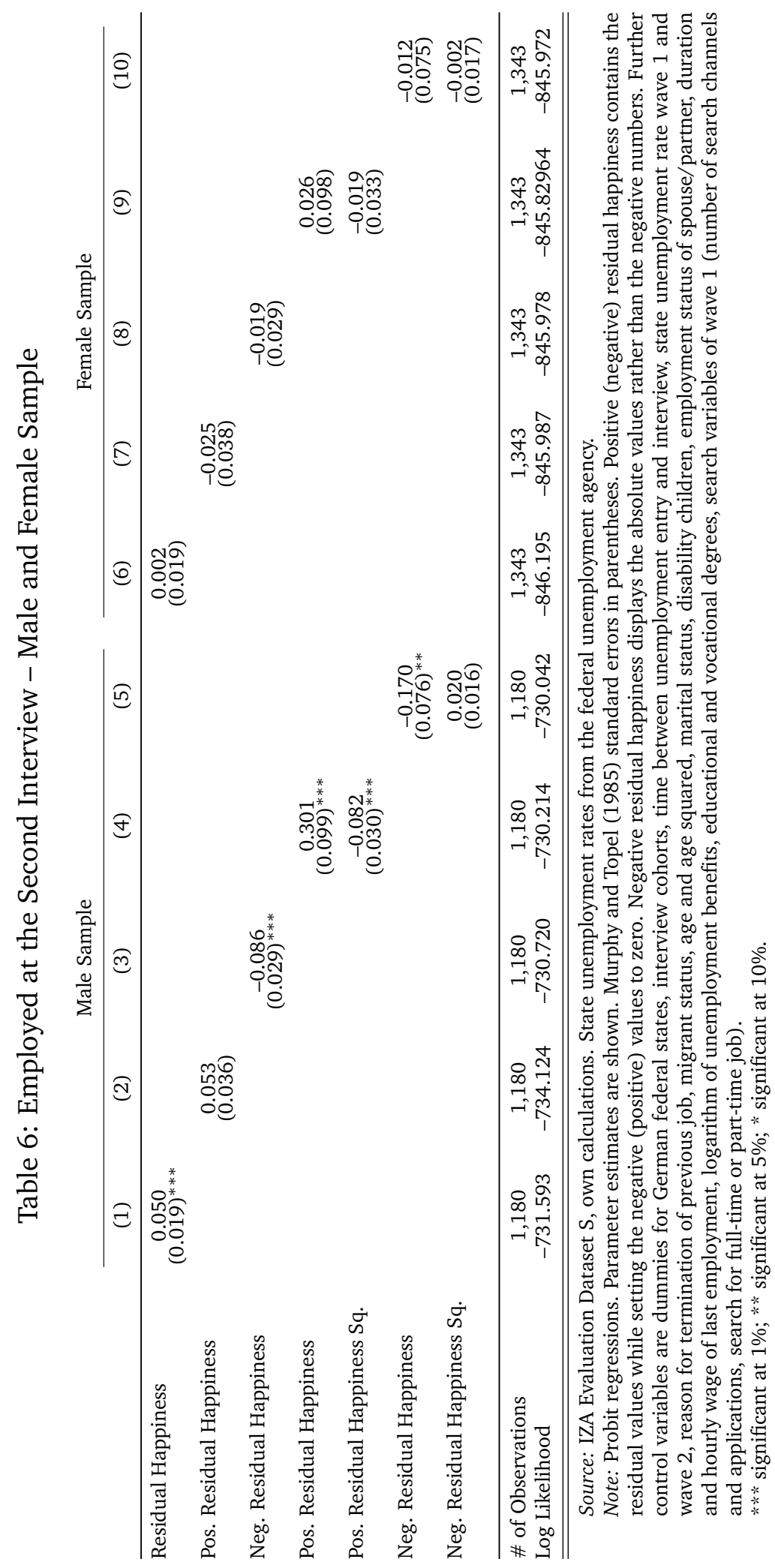




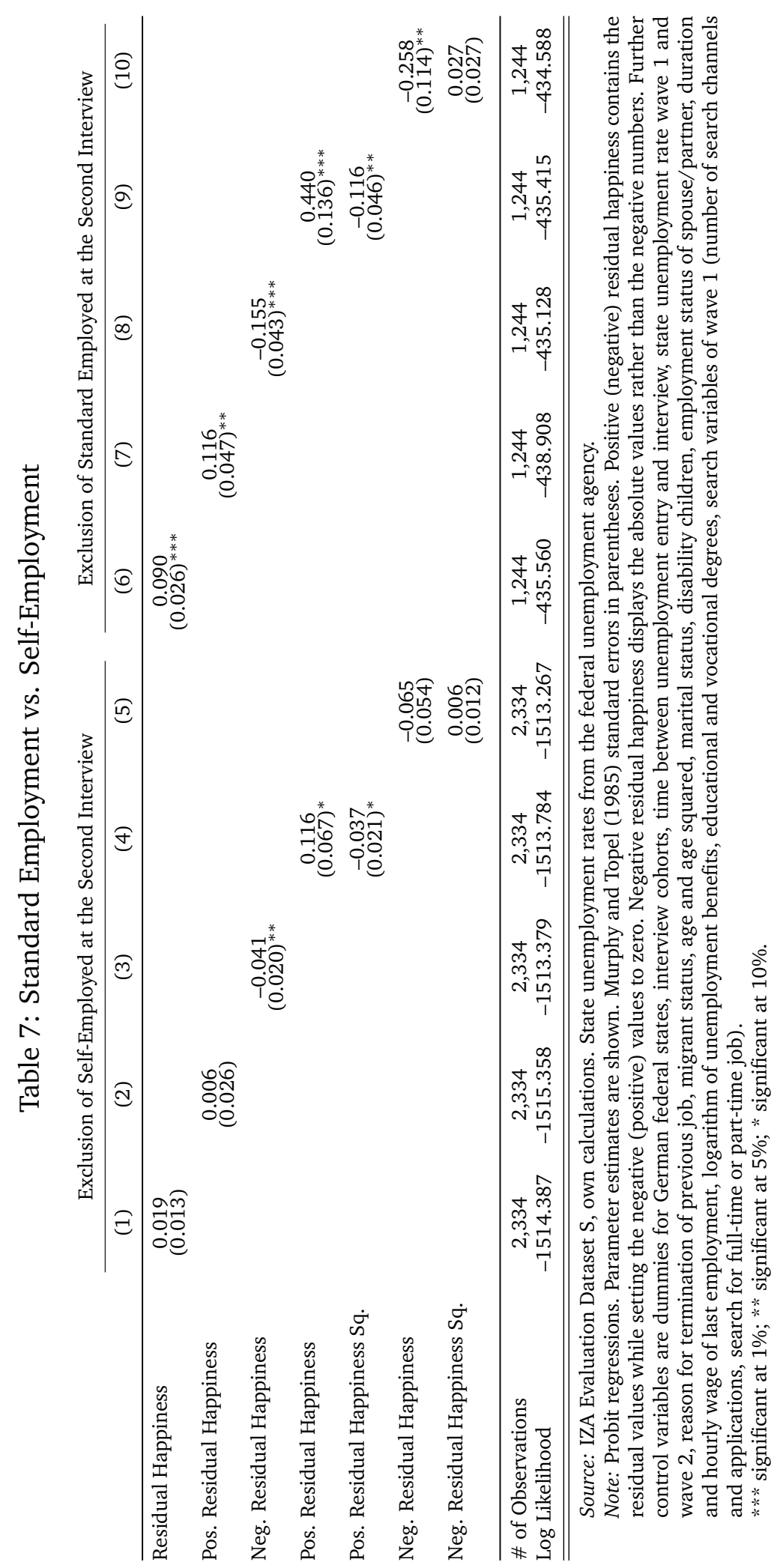




\section{Table 8: Employed at the Second Interview - With LOC Index}

(1)

Residual Happiness

Locus of Control Index Std.

Pos. Residual Happiness

Locus of Control Index Std.

Neg. Residual Happiness

Locus of Control Index Std.

Pos. Residual Happiness

Pos. Residual Happiness Sq.

Locus of Control Index Std.

Neg. Residual Happiness

Neg. Residual Happiness Sq.

Locus of Control Index Std.
(2)

(3)

(4)

(5)
0.018
$(0.013)$

0.081

$(0.028)^{* * *}$

0.001

(0.026)

0.089

$(0.027)^{* * *}$
$(0.020)^{* * *}$

0.079

$(0.027)^{* * *}$

\begin{tabular}{lccccc}
\hline \# of Observations & 2,534 & 2,534 & 2,534 & 2,534 & 2,534 \\
Log Likelihood & -1611.790 & -1612.745 & -1610.597 & -1610.7544 & -1610.498 \\
\hline
\end{tabular}

0.125
$(0.067)$

$-0.042$

$(0.021)^{* *}$

0.084

$(0.028)^{* *}$

Source: IZA Evaluation Dataset S, own calculations. State unemployment rates from the federal unemployment agency.

Note: Probit regressions. Parameter estimates are shown. Murphy and Topel (1985) standard errors in parentheses. Positive (negative) residual happiness contains the residual values while setting the negative (positive) values to zero. Negative residual happiness displays the absolute values rather than the negative numbers. Further control variables are dummies for German federal states, interview cohorts, time between unemployment entry and interview, state unemployment rate wave 1 and wave 2, reason for termination of previous job, migrant status, age and age squared, marital status, disability children, employment status of spouse/partner, duration and hourly wage of last employment, logarithm of unemployment benefits, educational and vocational degrees, search variables of wave 1 (number of search channels and applications, search for full-time or part-time job).

$* * *$ significant at $1 \% ; * *$ significant at $5 \% ; *$ significant at $10 \%$. 
Table 9: Logit Estimation: Probability to Respond in the Second Wave

\begin{tabular}{|c|c|c|}
\hline \multirow[b]{2}{*}{ Interview Cohort (Reference: Cohort 1) } & \multicolumn{2}{|c|}{ Interview Wave 2} \\
\hline & & \\
\hline Cohort 2 & $0.806^{* * *}$ & $(0.164)$ \\
\hline Cohort 3 & $0.982^{* * *}$ & $(0.168)$ \\
\hline Cohort 4 & $1.183^{* * *}$ & $(0.164)$ \\
\hline Cohort 5 & $0.466^{* * *}$ & $(0.157)$ \\
\hline Cohort 6 & $1.165^{* * *}$ & $(0.152)$ \\
\hline Cohort 7 & $1.038^{* * *}$ & $(0.158)$ \\
\hline Cohort 8 & $0.890^{* * *}$ & $(0.166)$ \\
\hline Cohort 9 & 0.0518 & $(0.160)$ \\
\hline Cohort 10 & $1.218^{* * *}$ & $(0.160)$ \\
\hline Cohort 11 & $1.115^{* * *}$ & $(0.154)$ \\
\hline Cohort 12 & $1.183^{* * *}$ & $(0.153)$ \\
\hline \multicolumn{3}{|c|}{ Time between Unemployment Entry and Interview (Reference: 1 Month) } \\
\hline 2 Months & $-0.139^{*}$ & $(0.082)$ \\
\hline 3 Months & $-0.242^{* *}$ & $(0.100)$ \\
\hline 4 Months & $-0.374^{*}$ & $(0.222)$ \\
\hline Net Hourly Wage of Last Job (Euros) & 0.006 & $(0.009)$ \\
\hline \multicolumn{3}{|l|}{ Duration of Last Job (Reference: Until 1 Year) } \\
\hline 1 to 5 Years & -0.062 & $(0.072)$ \\
\hline 5 to 10 Years & 0.031 & $(0.103)$ \\
\hline More than 10 Years & -0.051 & $(0.109)$ \\
\hline 0 Months & -0.295 & $(0.283)$ \\
\hline Male & 0.022 & $(0.065)$ \\
\hline Age & 0.031 & $(0.027)$ \\
\hline Age Squared & -0.012 & $(0.036)$ \\
\hline Disabled & -0.016 & $(0.129)$ \\
\hline \multicolumn{3}{|l|}{ Marital Status (Reference: Divorced/Widowed) } \\
\hline Married & 0.067 & $(0.100)$ \\
\hline Single & 0.105 & $(0.104)$ \\
\hline Partner (Reference: No Partner) & -0.175 & $(0.118)$ \\
\hline \multicolumn{3}{|l|}{ Educational Degree (Reference: No Degree) } \\
\hline Secondary School (9 Yrs.) & -0.010 & $(0.286)$ \\
\hline Secondary School (10 Yrs.) & 0.160 & $(0.287)$ \\
\hline Technical College Entrance Qualification (11-12 Yrs.) & 0.342 & $(0.314)$ \\
\hline General Qualification for University Entrance (12-13 Yrs.) & $0.528^{*}$ & $(0.297)$ \\
\hline \multicolumn{3}{|l|}{ Vocational Degree (Reference: No Degree) } \\
\hline Apprenticeship (Dual System) & $0.220^{* *}$ & $(0.107)$ \\
\hline Specialized Vocational School & $0.315^{* *}$ & $(0.132)$ \\
\hline University, Technical College & $0.393^{* * *}$ & $(0.146)$ \\
\hline Children in Household & $0.200 * * *$ & $(0.0745)$ \\
\hline \multicolumn{3}{|l|}{ Migrant Status (Reference: Native) } \\
\hline 1st Generation Migrant & $-0.394^{* * *}$ & $(0.103)$ \\
\hline 2nd Generation Migrant & -0.021 & $(0.111)$ \\
\hline Constant & $-2.024^{* * *}$ & $(0.573)$ \\
\hline \# of Observations & \multicolumn{2}{|c|}{4,728} \\
\hline Log Likelihood & \multicolumn{2}{|c|}{-3057.752} \\
\hline
\end{tabular}

Source: IZA Evaluation Dataset S, own calculations.

Notes: Standard errors in parentheses. Further control variables include dummies for German federal states.

$* * *$ significant at $1 \% ; * *$ significant at $5 \% ; *$ significant at $10 \%$. 


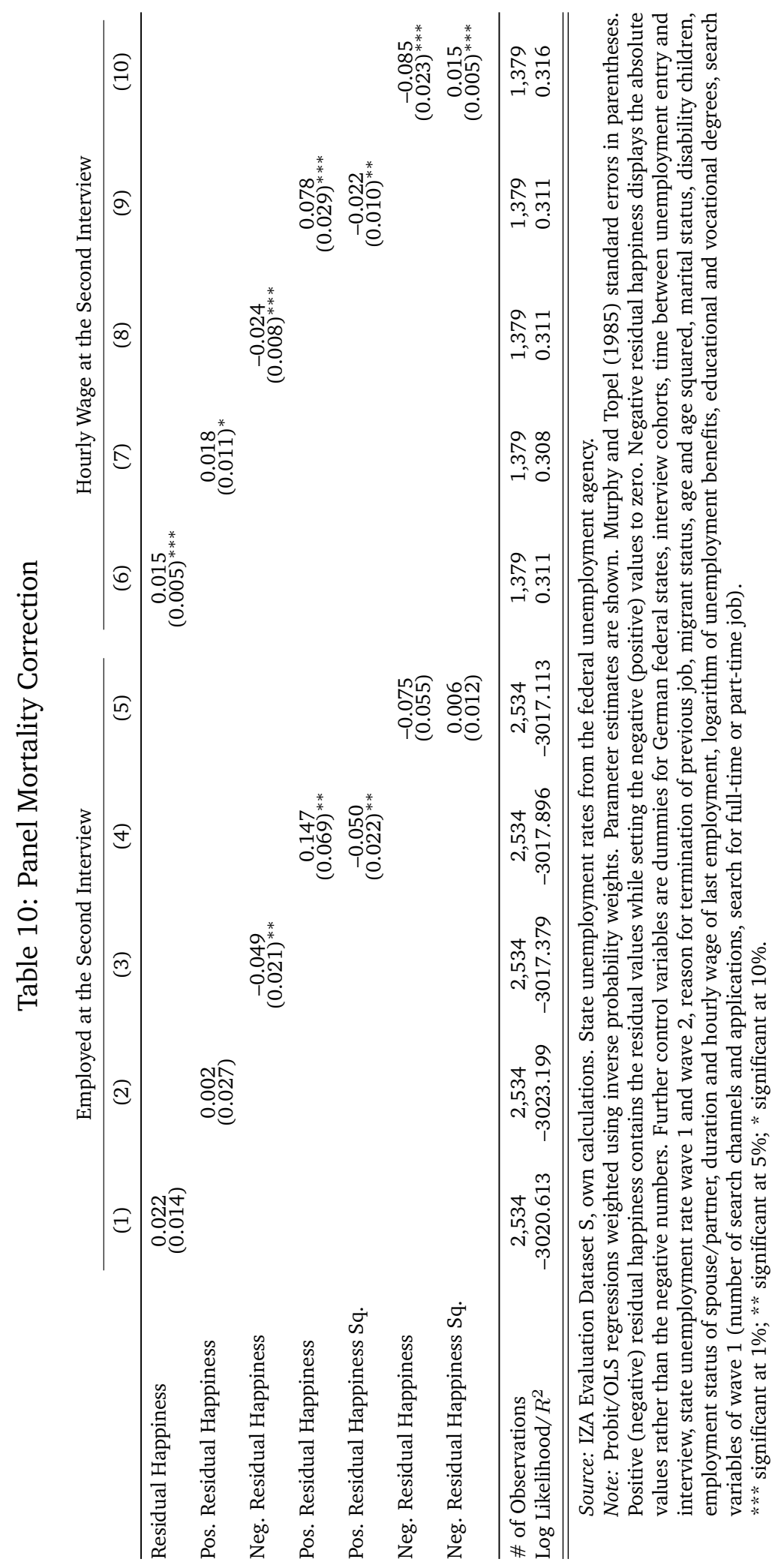

